\title{
Protective effects of Cambodian medicinal plants on tert-butyl hydroperoxide-induced hepatotoxicity via Nrf2-mediated heme oxygenase-1
}

\author{
DONG-SUNG LEE ${ }^{1}$, SAMELL KEO $^{2}$, SUN-KAING CHENG $^{3}$, HYUNCHEOL OH $^{2}$ and YOUN-CHUL KIM ${ }^{2}$ \\ ${ }^{1}$ College of Pharmacy, Chosun University, Dong-gu, Gwangju 61452; ${ }^{2}$ College of Pharmacy, Wonkwang University, Iksan, \\ Jeonbuk 54538, Republic of Korea; ${ }^{3}$ Faculty of Pharmacy, University of Health Sciences, \\ Phnom Penh 12201, Cambodia
}

Received September 9, 2015; Accepted September 13, 2016

DOI: $10.3892 / \mathrm{mmr} .2016 .6011$

\begin{abstract}
Liver diseases are considered to be primary contributors to morbidity and mortality rates in humans. Oxidative stress is critical in liver injury, and oxidant-induced liver injury may be caused by toxins, including tert-butyl hydroperoxide ( $t$-BHP). The present study investigated the hepatoprotective activities of 64 crude ethanol extracts of Cambodian medicinal plants against $t$-BHP-induced cytotoxicity in human liver-derived HepG2 cells, and assessed their cytoprotective mechanism pertaining to the expression of heme oxygenase (HO)-1 and nuclear factor E2-related factor 2 (Nrf2). Protective effects in HepG2 cells were determined by MTT assay. Protein expression levels of $\mathrm{HO}-1$ and $\mathrm{Nrf} 2$ were determined by western blotting and mRNA expression levels were determined by reverse transcription-quantitative polymerase chain reaction. Of the 64 extracts, 19 extracts exhibited high hepatoprotective activities: Ampelocissus martini, Bauhinia bracteata, Bombax ceiba, Borassus flabellifer, Cardiospermum halicacabum, Cayratia trifolia, Cinnamomum caryophyllus, Cyperus rotundus, Dasymaschalon lomentaceum, Ficus benjamina, Mangifera duperreana, Morinda citrifolia, Pandanus humilis, Peliosanthes weberi, Phyllanthus emblica, Quisqualis indica, Smilax glabra, Tinospora crispa and Willughbeia cochinchinensis, with half maximal effective concentrations ranging between 59.23 and $157.80 \mu \mathrm{g} / \mathrm{ml}$. Further investigations revealed that, of these 19 extracts, HO-1 and $\mathrm{Nrf} 2$ were expressed in P.weberi and T.crispa expressed in a dose-dependent manner. In addition, the activities of reactive oxygen species were suppressed following treatment of these
\end{abstract}

Correspondence to: Professor Youn-Chul Kim, College of Pharmacy, Wonkwang University, 460 Iksan-daero, Iksan, Jeonbuk 54538, Republic of Korea

E-mail: yckim@wku.ac.kr

Key words: Cambodian medicinal plants HepG2 cells, tert-Butyl hydroperoxide, heme oxygenase-1, nuclear factor E2-related factor 2, hepatoprotective activity two extracts in $t$-BHP-induced HepG2 cells. These results indicated that, of the 64 Cambodian plants, $P$. weberi and $T$. crispa exhibited hepatoprotective effects on $t$-BHP-induced cytotoxicity in HepG2 cells, possibly by the induction of Nrf2-mediated expression of HO-1. Taken together, these results suggested that T. crispa or $P$. weberi may offer potential for therapeutic applications in liver disease characterized by oxidative stress.

\section{Introduction}

Cambodia is a tropical country featuring plateaus, flat plains, hills and highland, the area of which is covered predominantly in forest. By virtue of its tropical climate, Cambodia has a diverse range of natural resources, amongst which plants are primarily used for complementary medicines by the local population. As many as 515 species amongst 134 families of medicinal plants have been found in Cambodia (1), allowing Cambodians to couple the use of medicinal plants with their traditional treatment of diseases. Cambodian medicinal plants are crucial in folk medicine in communities, with traditional healers offering assurance for their curable effects (2). According to the Ministry of Health in Cambodia, $45 \%$ of the Cambodian population use herbal plants for therapeutic purposes, despite a shortage of scientific evidence (3).

Liver disease, predominantly attributed to hepatitis and alcoholism, is considered a primary contributor to morbidity and mortality rates in humans. The accumulation of deleterious substances in hepatocytes caused by infection, injury, exposure to xenobiotics, autoimmunity or genetic disorders may lead to liver damage in the form of inflammation, scarring, cirrhosis or liver dysfunction $(4,5)$. Oxidative stress is critical in liver injury and may be triggered by reactive oxygen species (ROS) generated by various signal transduction pathways (6). Oxidant-induced liver injury is caused by toxins, including tert-Butyl hydroperoxide ( $t$-BHP), which exerts cytotoxic effects through glutathione (GSH) depletion coupled with intracellular over-influx of $\mathrm{Ca}^{2+}(4,7)$. Although there is general recognition that the drugs currently available for treating patients with liver disease are mandatory, natural products originating from plants have attracted considerable 
interest among hepatologists in terms of their efficacy and safety (8).

Traditional medicinal plants have long been used in folk medicine for ameliorating liver diseases. A number of these plants have shown potential in the treatment of liver disease due to their therapeutic mechanisms. For example, Silybum marianum and Picrorhiza kurroa have been confirmed to be clinically efficacious in the treatment of toxic hepatitis, fatty liver disease, cirrhosis, ischemic injury, radiation toxicity and viral hepatitis, based upon their antioxidative, antilipid peroxidative, antifibrotic, anti-inflammatory, immunomodulatory and liver regenerating effects (9). In addition, phytochemicals, including glycyrrhizin, matrine and silymarin, have been shown to exert therapeutic effects against hepatitis, alcoholic liver disease and liver cirrhosis (10). Phytochemicals protect hepatocytes (11) via the induction of heme oxygenase-1 (HO-1), which is catabolized to produce carbon monoxide, biliverdin and free iron (12). HO-1 is well-known as a valuable therapeutic candidate as it exerts anti-inflammatory, anti-apoptotic and antiproliferative effects (13). In addition, HO-1 is understood to be upregulated in the liver and splanchnic organs during portal hypertension (14) by the activation of nuclear factor-E2-related factor-2 (Nrf2) (15). Nrf2 is known to be important in the regulation of phase II detoxifying enzymes and associated proteins, including $\mathrm{HO}-1, \mathrm{GSH}$, catalase, superoxide dismutase, glutathione-S-transferase, $\gamma$-glutamyl cysteine ligase, $\mathrm{NAD}(\mathrm{P}) \mathrm{H}$ : quinone oxidoreductase-1, glutathione peroxidase and glutathione reductase (16). Nrf2-regulated phase II detoxifying enzymes can be critical in protecting the liver from oxidative stress imposed by ROS $(15,16)$. Alcoholic liver disease (ALD) is reported to affect the Cambodian population (17) due to high levels of alcohol consumption among men and women (18). Several species of Cambodian medicinal plants have been used for the treatment of ALD via a number of traditional approaches. However, the majority of these plants have received limited scientific investigation, particularly screening assays of their hepatoprotective activities (19).

Thus, the present study was designed to determine the hepatoprotective characteristics of 64 Cambodian plants by examining the cytoprotective effects of the Cambodian plant extracts against $t$-BHP-induced hepatotoxicity in HepG2 cells. Several laboratories have used human liver-derived HepG2 cells as a model for investigating hepatocyte proliferation and function; these cells perform several of the functions of normal hepatocytes, including the secretion of plasma proteins and extensive degradation of insulin (20). Therefore, HepG2 cells were selected for use in the present study. Selective extracts with hepatoprotective effects were further evaluated to examine their cytoprotective mechanism associated with the activities of ROS, HO-1 and Nrf2.

\section{Materials and methods}

Chemicals and reagents. Roswell Park Memorial Institute (RPMI) medium, fetal bovine serum (FBS), trypsin-EDTA solution and antibiotic-antimycotic solution (containing 10,000 units of penicillin, 10,000 $\mu \mathrm{g}$ of streptomycin and $25 \mu \mathrm{g}$ of amphotericin $\mathrm{B} / \mathrm{ml}$ ) were purchased from Gibco; Thermo Fisher Scientific, Inc. (Waltham, MA, USA). Tin protoporphyrin IX (SnPP), an inhibitor of HO activity, was obtained from Porphyrin Products (Logan, UT, USA). All other relevant chemicals and reagents were obtained from Sigma-Aldrich; Merck Millipore (Darmstadt, Germany).

Preparation of Cambodian plants. A total of 64 Cambodian plants were imported from O'reusey Market (Phnom Penh, Cambodia). All plants were identified by Professor Sun Kaing Cheng (Laboratory of Phytochemistry, Faculty of Pharmacy, University of Health Sciences (Phnom Penh, Cambodia). The herbarium specimens (no. WKP-2013-23-WKP-2013-86) were stored at the College of Pharmacy, Wonkwang University (Iksan, Korea). Dry plants (20 g each) were extracted with $70 \%$ ethanol (1 liter of each) for $2 \mathrm{~h}$, and the extracts were concentrated in vacuo to obtain $70 \%$ ethanol extracts. Plant extraction was supported by the College of Pharmacy, Wonkwang University.

Cell culture and viability assay. Human liver-derived HepG2 cells were obtained from American Type Culture Collection (Manassas, VA, USA). The cells were maintained at $5 \times 10^{5}$ cells $/ \mathrm{ml}$ in RPMI 1640 medium supplemented with $10 \%$ heat-inactivated FBS, penicillin $\mathrm{G}\left(100 \mathrm{U} / \mathrm{ml}^{-1}\right)$, streptomycin $\left(100 \mathrm{mg} \cdot \mathrm{ml}^{-1}\right)$ and L-glutamine $(2 \mathrm{mM})$, and were incubated at $37^{\circ} \mathrm{C}$ in a humidified atmosphere containing $5 \% \mathrm{CO}_{2}$ and $95 \%$ air. The cells were pretreated for $3 \mathrm{~h}$ with the indicated concentrations of Cambodian plant extract and stimulated for $24 \mathrm{~h}$ with $t$-BHP. The control group was treated with equal volume of DMSO as the extracts. The determination of cell viability was performed using a 3-(4,5-dimethylthiazol-2-yl)-2,5-diphenyltetrazolium bromide (MTT) assay. MTT $\left(2.5 \mathrm{mg} \cdot \mathrm{ml}^{-1} ; 50 \mu \mathrm{l}\right)$ was added to each well, containing a cell suspension of $2 \times 10^{5}$ cells $/ \mathrm{ml}$ in 96 -well plates, at a final concentration of $0.5 \mathrm{mg} \cdot \mathrm{ml}^{-1}$. The mixture was incubated for $3-4 \mathrm{~h}$ at $37^{\circ} \mathrm{C}$, and the liquid was removed from the wells in turn. Subsequently, DMSO $(150 \mu 1)$ was added to each well, and the absorbance was read at $540 \mathrm{~nm}$ on a UV Max microplate reader (Bio-Rad Laboratories, Inc., Hercules, CA, USA). The relative optical density of formazan in the control group, which contained cells treated with neither glutamate nor the plant extracts, was taken as $100 \%$ viability.

Western blot analysis. The human liver-derived HepG2 cells were harvested and pelleted by centrifugation at $200 \mathrm{x} g$ for $3 \mathrm{~min}$ at $4^{\circ} \mathrm{C}$. The cells were then washed with PBS and lysed with $20 \mathrm{mM}$ Tris-HCl buffer ( $\mathrm{pH}$ 7.4) containing a protease inhibitor mixture $(0.1 \mathrm{mM}$ phenylmethanesulfonyl fluoride, $5 \mathrm{mg} / \mathrm{ml}$ aprotinin, $5 \mathrm{mg} / \mathrm{ml}$ pepstatin A and $1 \mathrm{mg} / \mathrm{ml}$ chymostatin). The protein concentration was determined using a Lowry protein assay kit (P5626; Sigma-Aldrich; Merck Millipore). An equal quantity of protein from each sample $(30 \mu \mathrm{g})$ was resolved using $12 \%$ sodium dodecyl sulfate-polyacrylamide gel electrophoresis and then electrophoretically transferred onto a Hybond enhanced chemiluminescence (ECL) nitrocellulose membrane (Bio-Rad Laboratories, Inc.). The membrane was blocked with $5 \%$ skimmed milk and sequentially incubated with primary antibodies against HO-1 (1:1,000; cat. no. sc-10789), Nrf2 (1:1,000; cat. no. sc-722), Lamin B (1:1,000; cat. no. sc-6216), actin (1:1,000; cat. no. sc-1616) all obtained from Santa Cruz Biotechnology, Inc. (Dallas, TX, USA), a 
further anti-HO-1 antibody (1:1,000; Merck Millipore; cat. no. 374090) and horseradish peroxidase-conjugated secondary antibodies (1:1,000; Santa Cruz Biotechnology, Inc.; cat. nos. sc-2741 and sc-2004) followed by ECL detection.

Preparation of nuclear and cytosolic fractions. The cells were homogenized (1:20, w/v) in PER Mammalian Protein Extraction buffer (Pierce; Thermo Fisher Scientific, Inc.) containing freshly added protease inhibitor cocktail I (EMD Millipore, Billerica, MA, USA) and $1 \mathrm{mM}$ phenylmethylsulfonyl fluoride. The cytosolic fraction of the cell was prepared by centrifugation at $15,000 \times \mathrm{g}$ for $10 \mathrm{~min}$ at $4^{\circ} \mathrm{C}$. The nuclear and cytoplasmic extracts of the cells were prepared using NE-PER nuclear and cytoplasmic extraction reagents (Pierce; Thermo Fisher Scientific, Inc.), respectively.

Reverse transcription-quantitative polymerase chain reaction (RT-qPCR) analysis. Total RNA was isolated from the cells using TRIzol (Invitrogen; Thermo Fisher Scientific, Inc.), in accordance with the manufacturer's protocol, and quantified spectrophotometrically at $260 \mathrm{~nm}$. The total RNA $(1 \mu \mathrm{g})$ was reverse-transcribed using the High Capacity RNA-to-cDNA kit (Applied Biosystems; Thermo Fisher Scientific, Inc.). The cDNA was then amplified using the SYBR Premix Ex Taq kit (Takara Bio, Inc., Shiga, Japan) using a StepOnePlus Real-Time PCR system (Applied Biosystems; Thermo Fisher Scientific, Inc.). Briefly, each $20 \mu \mathrm{l}$ of reaction volume contained $10 \mu \mathrm{l}$ of SYBR-Green PCR master mix, $0.8 \mu \mathrm{M}$ of each primer, and diethyl pyrocarbonate-treated water. The primer sequences were designed using PrimerQuest (Integrated DNA Technologies, Cambridge, MA, USA; www.idtdna. com/Primerquest/Home/Index). The primer sequences were as follows: HO-1, forward 5'-CTCTTGGCTGGCTTCCTT-3' and reverse 5'-GGCTCCTTCCTCCTTTCC-3' and glyceraldehyde 3-phosphate dehydrogenase (GAPDH), forward 5'-ACTTTGGTATCGTGGAAGGACT-3' and reverse 5'-GTA GAGGCAGGGATGATGTTCT-3. The optimal conditions for PCR amplification of the cDNA were established according to the manufacturer's protocol. The data were analyzed using StepOne software version 2.3 (Applied Biosystems; Thermo Fisher Scientific, Inc.), and the cycle number at the linear amplification threshold $(\mathrm{Cq})$ values for the endogenous control gene (GAPDH) and the target gene were recorded. Relative gene expression, calculated as the target gene expression normalized to the expression of the endogenous control gene, was calculated using the comparative $\mathrm{Cq}$ method $\left(2^{-\Delta \Delta \mathrm{Cq}}\right)(21)$.

Nuclear magnetic resonance (NMR) analysis. The ${ }^{1} \mathrm{H}-\mathrm{NMR}$ spectra of the ethanolic extracts of T.crispa and P.weberi were recorded in $\left(\mathrm{CD}_{3}\right) \mathrm{CO}_{2}$ and $\mathrm{D}_{2} \mathrm{O}$ using a JEOL JNM ECP-400 spectrometer $(400 \mathrm{MHz}$ for $1 \mathrm{~h}$ ), and chemical shifts were referenced relative to the residual solvent peak. The resultant spectra of the possible functional group present in the plants were determined.

Statistical analysis. The data are expressed as the mean \pm standard deviation of at least three independent experiments. To compare three or more groups, one-way analysis of variance, followed by the Newman-Keuls post-hoc test, was used. Statistical analysis was performed using GraphPad Prism software version 3.03 (GraphPad Software, Inc., San Diego, CA, USA). $\mathrm{P}<0.05$ was considered to indicate a statistically significant difference.

\section{Results}

Effects of Cambodian plant extracts on $t$-BHP-induced hepatotoxicity in human liver-derived HepG2 cells. The ethanolic extracts of 64 Cambodian plants on human liver-derived HepG2 cells were assessed in vitro. As shown in Table I, 51 plants exhibited a cytoprotection value of $<80 \%$, whereas 19 plants showed a cytoprotection value of $>80 \%$. At a final concentration of $100 \mu \mathrm{g} / \mathrm{ml}$, plant extracts of B. flabellifer (root), C. halicacabum (whole plant), C. trifolia (stem), C. caryophyllus (bark), C. rotundus (rhizome), F. benjamina (stem), Q. indica (whole plant), S. glabra (rhizome) and W. cochinchinensis (stem) resulted in maintained cell viability (Table I). At a final concentration of $300 \mu \mathrm{g} / \mathrm{ml}$, the plant extracts A. martinii (root), B. bracteata (stem), B. ceiba (bark), D. lomentaceum (stem), M. duperreana (bark), M. citrifolia (fruit), P. humilis (stem), P. weberi (whole plant), P. emblica (fruit) and T. crispa (stem) resulted in maintained cell viability (Table I). The 19 plant extracts with cytoprotective values $>80 \%$ at a final concentration of $100 \mu \mathrm{g} / \mathrm{ml}$ were used for further analysis (Table II). The results revealed the half maximal effective concentration $\left(\mathrm{EC}_{50}\right)$ values for B. flabellifer $(66.25 \mu \mathrm{g} / \mathrm{ml}), C$. halicacabum $(63.18 \mu \mathrm{g} / \mathrm{ml})$, C. trifolia $(59.23 \mu \mathrm{g} / \mathrm{ml})$, C. caryophyllus $(64.33 \mu \mathrm{g} / \mathrm{ml})$, C. rotundus $(68.75 \mu \mathrm{g} / \mathrm{ml}), F$. benjamina $(62.98 \mu \mathrm{g} / \mathrm{ml}), Q$. indica $(62.9 \mu \mathrm{g} / \mathrm{ml})$, S. glabra $(80.41 \mu \mathrm{g} / \mathrm{ml})$, W. cochinchinensis $(72.95 \mu \mathrm{g} / \mathrm{ml})$, A. martinii $(121.1 \mu \mathrm{g} / \mathrm{ml})$, B. bracteata $(138.9 \mu \mathrm{g} / \mathrm{ml})$, B. ceiba $(148.8 \mu \mathrm{g} / \mathrm{ml})$, D. lomentaceum $(125.7 \mu \mathrm{g} / \mathrm{ml})$, M.duperreana $(105.2 \mu \mathrm{g} / \mathrm{ml})$, M. citrifolia $(157.8 \mu \mathrm{g} / \mathrm{ml}), P$.humilis $(151.3 \mu \mathrm{g} / \mathrm{ml})$, P.weberi $(121.7 \mu \mathrm{g} / \mathrm{ml})$, P. emblica $(144.9 \mu \mathrm{g} / \mathrm{ml})$ and T. crispa $(144.3 \mu \mathrm{g} / \mathrm{ml})$, as shown in Table II.

Effects of Cambodian plant extracts on the $m R N A$ and protein expression levels of HO-1 in human liver-derived Hep 2 cells. HO-1 has been reported to be upregulated in hepatocytes (14). Therefore, the present study performed further screening of the 19 plant extracts for the protein expression of HO-1 in the HepG2 cells (Fig. 1). Whether treatment of the HepG2 cells with the selected extracts affected the mRNA expression of HO-1 was subsequently examined. The protein and mRNA expression levels were determined following treatment for $12 \mathrm{~h}$. Amongst the 19 plant extracts, the T. crispa and P. weberi extracts significantly increased the protein (Fig. 1E and J) and mRNA (Fig. 2A and B) levels of HO-1 in a dose-dependent manner, with maximal values observed at $400 \mu \mathrm{g} / \mathrm{ml}$. The HO-1 inducer, curcumin, was used at a concentration of $20 \mu \mathrm{M}$ as a positive control, which also increased the expression of HO-1.

Effects of the upregulation of $\mathrm{HO}-1$ on $t$-BHP-induced hepatotoxicity and the inhibition of ROS generation by T. crispa or P. weberi extracts. HO-1 is considered to possess cytoprotective effects against oxidative stress-induced cell damage, notably in HepG2 cells (22). Thus, the present study investigated whether the upregulation of HO-1 triggered by T. crispa or $P$. weberi extracts mediated these cytoprotective 
Table I. Protective effects of ethanolic extracts (100 and $300 \mu \mathrm{g} / \mathrm{ml}$ ) derived from Cambodian plants on $t$-BHP-induced hepatotoxicity in HepG2 cells.

\begin{tabular}{|c|c|c|c|c|c|}
\hline \multirow[b]{2}{*}{ No. } & \multirow[b]{2}{*}{ Plant family } & \multirow[b]{2}{*}{ Plant species } & \multirow[b]{2}{*}{ Plant region } & \multicolumn{2}{|c|}{ Protection $(\%)$} \\
\hline & & & & $100 \mu \mathrm{g} / \mathrm{ml}$ & $300 \mu \mathrm{g} / \mathrm{ml}$ \\
\hline 1 & Anacardiaceae & Anacardium occidentale $\mathrm{L}$. & Bark & 11.5 & 45.1 \\
\hline 2 & & Mangifera duperreana pierre & Bark & 45.1 & 85.1 \\
\hline 3 & Annonaceae & Cananga latifolia finet \& gagnep. & Stem & -15.1 & -85.1 \\
\hline 4 & & Dasymaschalon lomentaceum finet \& gagnep. & Stem & 48.8 & 87.8 \\
\hline 5 & Apocynaceae & Calotropis procera (aiton) R. Br. & Stem & -33.9 & -19.8 \\
\hline 6 & & Streptocaulon juventas (Lour.) merr. & Root & -26.7 & -33.1 \\
\hline 7 & & Willughbeia cochinchinensis (Pierre) K. Schum. & Stem & 88.7 & 17.5 \\
\hline 8 & Araceae & Alocasia macrorrhiza schott. & Stem & -3.3 & -17.4 \\
\hline 9 & & Amorphophallus harmandii engl. \& gehrm. & Tuber & 1.9 & 19.3 \\
\hline 10 & Arecaceae & Borassus flabellifer $\mathrm{L}$. & Root & 83.1 & 12.4 \\
\hline 11 & & Borassus flabellifer $\mathrm{L}$. & Male flower & 48.4 & -30.1 \\
\hline 12 & Asparagaceae & Dracaena angustifolia (medik.) roxb. & Stem & 9.6 & 51.7 \\
\hline 13 & & Peliosanthes weberi (L. modr.) N. tanaka & Whole plant & 42.5 & 87.6 \\
\hline 14 & Asteraceae & Blumea balsamifera (L.) DC. & Stem & 26.9 & 47.2 \\
\hline 15 & Capparaceae & Crateva adansonii DC. & Bark & 0.7 & 1.9 \\
\hline 16 & Caricaceae & Carica papaya $\mathrm{L}$. & Root & 3.9 & 15.6 \\
\hline 17 & Combretaceae & Quisqualis indica $\mathrm{L}$. & Whole plant & 83.9 & 20.6 \\
\hline 18 & Costaceae & Costus speciosus (J. koenig) Sm. & Rhizome & -15.8 & -24.1 \\
\hline 19 & Cyperaceae & Cyperus rotundus $\mathrm{L}$. & Rhizome & 89.6 & 14.4 \\
\hline 20 & Dilleniaceae & Tetracera indica (christm. \& panz) merr. & Stem & 1.4 & 21.2 \\
\hline 21 & Dipterocarpaceae & Shorea siamensis miq. & Flowers & 55.8 & 69.3 \\
\hline 22 & Ebenaceae & Diospyros ehretioides wall. ex G. don & Root & 46.8 & -10.3 \\
\hline 23 & & Diospyros rhodocalyx kurz & Fruit & 0.7 & 3.5 \\
\hline 24 & Euphorbiaceae & Croton crassifolius geiseler & Rhizome & 10.1 & -31.2 \\
\hline 25 & Fabaceae & Bauhinia bracteata (benth.) baker & Stem & 36.0 & 88.1 \\
\hline 26 & & Cassia alata $\mathrm{L}$. & Stem & 30.4 & 30.0 \\
\hline 27 & & Dalbergia hancei benth. & Stem & 74.8 & 48.7 \\
\hline 28 & Lamiaceae & Gmelina asiatica $\mathrm{L}$. & Stem & 4.1 & 10.8 \\
\hline 29 & & Cinnamomum cambodianum lecomte & Bark & 57.0 & 54.5 \\
\hline 30 & & Cinnamomum caryophyllus (lour.) S. moore & Bark & 87.4 & 5.3 \\
\hline 31 & Lecythidaceae & Careya arborea roxb. & Bark & -76.1 & -16.7 \\
\hline 32 & Loganiaceae & Strychnos nux-vomica L. & Seed & 67.8 & 75.8 \\
\hline 33 & Malvaceae & Abutilon indicum (L.) sweet & Stem & 10.2 & 23.0 \\
\hline 34 & & Bombax ceiba $\mathrm{L}$. & Bark & 31.8 & 81.6 \\
\hline 35 & Meliaceae & Walsura villosa wall. ex wight $\&$ arn. & Bark & 42.5 & -34.3 \\
\hline 36 & Menispermaceae & Fibraurea tinctoria lour. & Stem & 37.9 & -80.8 \\
\hline 37 & & Tinospora crispa (L.) hook. f. \& thomson & Stem & 36.2 & 88.2 \\
\hline 38 & Moraceae & Ficus benjamina $\mathrm{L}$. & Stem & 87.7 & 21.9 \\
\hline 39 & & Morus alba $\mathrm{L}$. & Bark & 10.4 & 30.1 \\
\hline 40 & Pandanaceae & Pandanus humilis lour. & Stem & 40.9 & 85.3 \\
\hline 41 & Phyllanthaceae & Flueggea virosa (roxb. ex willd.) baill. & Wood & 14.2 & 50.3 \\
\hline 42 & & Phyllanthus emblica $\mathrm{L}$. & Fruit & 34.5 & 85.5 \\
\hline 43 & Piperaceae & Piper retrofractum vahl & Fruit & -8.5 & -12.9 \\
\hline 44 & Poaceae & Chrysopogon aciculatus (retz.) trin. & Whole plant & 50.3 & 48.6 \\
\hline 45 & & Coix lacryma-jobi $\mathrm{L}$. & Whole plant & 65.2 & 2.0 \\
\hline 46 & & Cynodon dactylon (L.) pers. & Aerial part & 70.4 & 24.0 \\
\hline 47 & & Imperata cylindrica (L.) raeusch. & Rhizome & 12.2 & 27.4 \\
\hline 48 & & Oryza rufipogon griff. & Whole plant & 20.3 & -15.3 \\
\hline 49 & Rubiaceae & Anthocephalus chinensis (lam.) rich. ex walp. & Wood & 27.1 & 45.5 \\
\hline
\end{tabular}


Table I. Continued.

\begin{tabular}{|c|c|c|c|c|c|}
\hline \multirow[b]{2}{*}{ No. } & \multirow[b]{2}{*}{ Plant family } & \multirow[b]{2}{*}{ Plant species } & \multirow[b]{2}{*}{ Plant region } & \multicolumn{2}{|c|}{ Protection (\%) } \\
\hline & & & & $100 \mu \mathrm{g} / \mathrm{ml}$ & $300 \mu \mathrm{g} / \mathrm{ml}$ \\
\hline 50 & & Gardenia obtusifolia roxb. ex hook. f. & Rhizome & -25.1 & -22.8 \\
\hline 51 & & Morinda citrifolia $\mathrm{L}$. & Fruit & 30.7 & 84.3 \\
\hline 52 & Rutaceae & Aegle marmelos (L.) corrêa & Fruit & 0.8 & 23.6 \\
\hline 53 & & Feroniella lucida swingle & Bark & -52.5 & -43.2 \\
\hline 54 & Sapindaceae & Cardiospermum halicacabum L. & Whole plant & 82.5 & 15.9 \\
\hline 55 & Simaroubaceae & Brucea javanica (L.) merr. & Whole plant & -65.9 & -42.0 \\
\hline 56 & & Smilax glabra roxb. & Rhizome & 84.4 & 15.8 \\
\hline 57 & Solanaceae & Physalis angulata $\mathrm{L}$. & Whole plant & -4.2 & -3.7 \\
\hline 58 & Urticaceae & Pouzolzia zeylanica (L.) benn. \& R. Br. & Whole plant & 17.0 & 3.9 \\
\hline 59 & Vitaceae & Ampelocissus martinii planch. & Root & 45.9 & 85.9 \\
\hline 60 & & Cayratia trifolia (L.) domin & Stem & 88.5 & 10.9 \\
\hline 61 & & Cissus modeccoides planch. & Stem & 59.8 & 25.4 \\
\hline 62 & & Leea rubra blume ex spreng. & Stem & 10.4 & 30.2 \\
\hline 63 & Zingiberaceae & Alpinia conchigera griff. & Rhizome & -44.8 & -42.0 \\
\hline 64 & & Amomum krervanh pierre ex gagnep. & Fruit & 10.7 & 8.8 \\
\hline
\end{tabular}

Curcumin was used as a reference compound. For pretreatment, samples were incubated for $2 \mathrm{~h}$ prior to exposure to $t$-BHP. $t$-BHP, tert-butyl hydroperoxide.

Table II. Protective effects of ethanolic extracts from Cambodian plants on $t$-BHP-induced hepatotoxicity in HepG2 cells .

\begin{tabular}{|c|c|c|c|}
\hline No. & Plant species & Plant region & $\mathrm{EC}_{50}(\mu \mathrm{g} / \mathrm{ml})$ \\
\hline 1 & Ampelocissus martinii planch. & Root & 121.1 \\
\hline 2 & Bauhinia bracteata (benth.) baker & Stem & 138.9 \\
\hline 3 & Bombax ceiba $\mathrm{L}$. & Bark & 148.8 \\
\hline 4 & Borassus flabellifer L. & Root & 66.2 \\
\hline 5 & Cardiospermum halicacabum $\mathrm{L}$. & Whole plant & 63.2 \\
\hline 6 & Cayratia trifolia (L.) domin & Stem & 59.2 \\
\hline 7 & Cinnamomum caryophyllus (Lour.) S. moore & Bark & 64.3 \\
\hline 8 & Cyperus rotundus $\mathrm{L}$. & Rhizome & 68.8 \\
\hline 9 & Dasymaschalon lomentaceum finet \& gagnep. & Stem & 125.7 \\
\hline 10 & Ficus benjamina L. & Stem & 63.0 \\
\hline 11 & Mangifera duperreana pierre & Bark & 105.2 \\
\hline 12 & Morinda citrifolia $\mathrm{L}$. & Fruit & 157.8 \\
\hline 13 & Pandanus humilis lour. & Stem & 151.3 \\
\hline 14 & Peliosanthes weberi (L. rodr.) N. tanaka & Whole plant & 121.7 \\
\hline 15 & Phyllanthus emblica L. & Fruit & 144.9 \\
\hline 16 & Quisqualis indica $\mathrm{L}$. & Whole plant & 62.9 \\
\hline 17 & Smilax glabra roxb. & Rhizome & 80.4 \\
\hline 18 & Tinospora crispa (L.) hook. f. \& thomson & Stem & 144.3 \\
\hline 19 & Willughbeia cochinchinensis (pierre) K. Schum. & Stem & 73.0 \\
\hline
\end{tabular}

Curcumin was used as a reference compound. For pretreatment, samples were incubated for $2 \mathrm{~h}$ prior to exposure to $t$-BHP. $\mathrm{EC}_{50}$, half maximal effective concentration; $t$-BHP, tert-butyl hydroperoxide.

effects. The HepG2 cells were co-treated with $400 \mu \mathrm{g} / \mathrm{ml}$ of $T$. crispa or $P$. weberi extracts for $12 \mathrm{~h}$ in the absence or presence of SnPP, an inhibitor of HO activity. These inhibitors significantly suppressed $T$. crispa/P. weberi extract-mediated protection (Fig. 3A and B). The T. crispa/P. weberi extract-induced upregulation of $\mathrm{HO}-1$ was also required for 
A

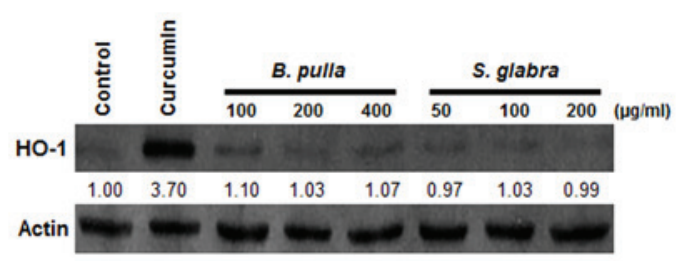

C

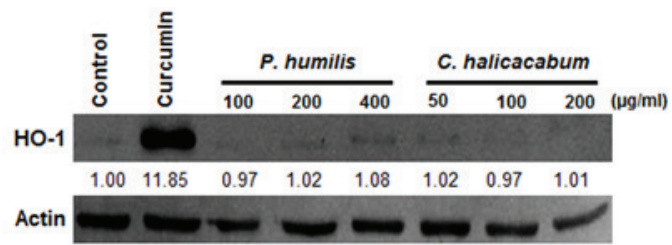

$\mathbf{E}$

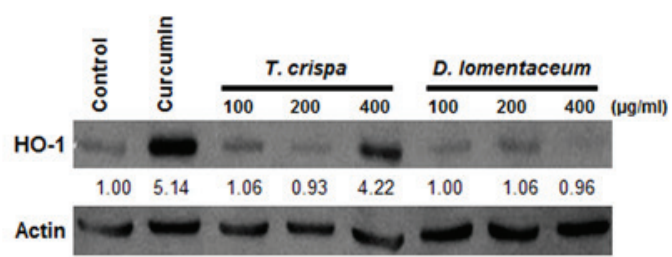

G

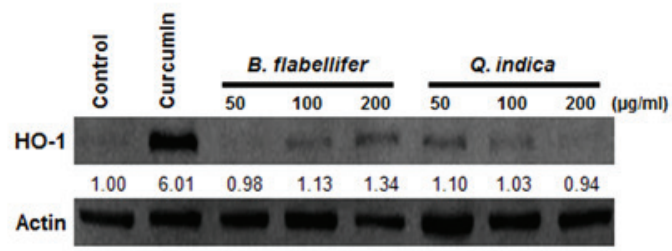

I

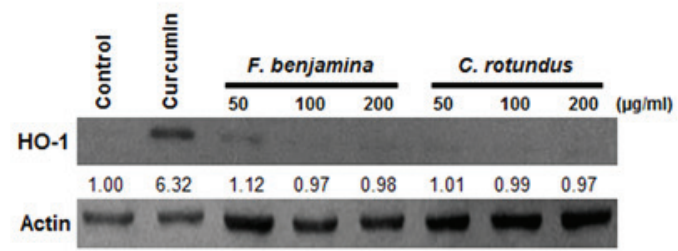

B
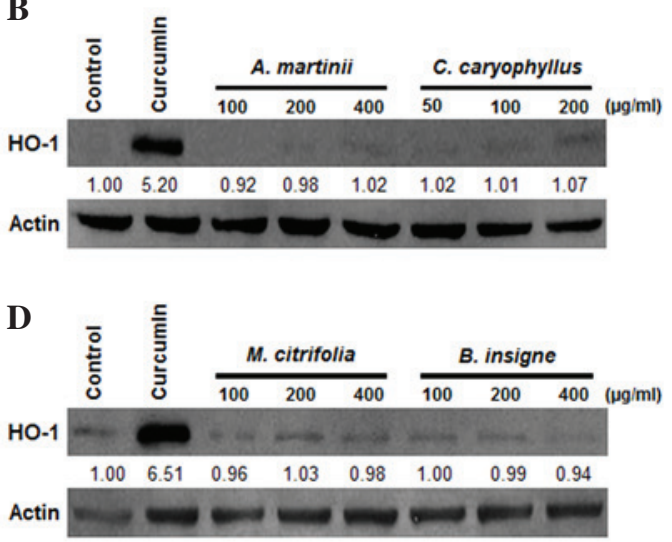

$\mathbf{F}$

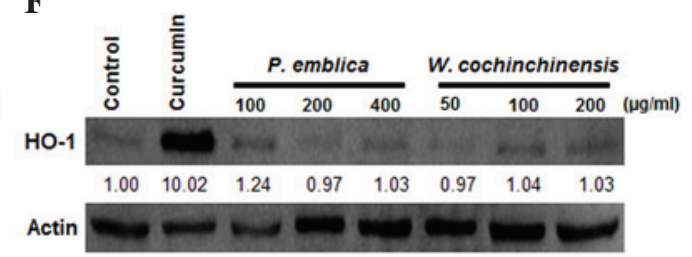

$\mathbf{H}$
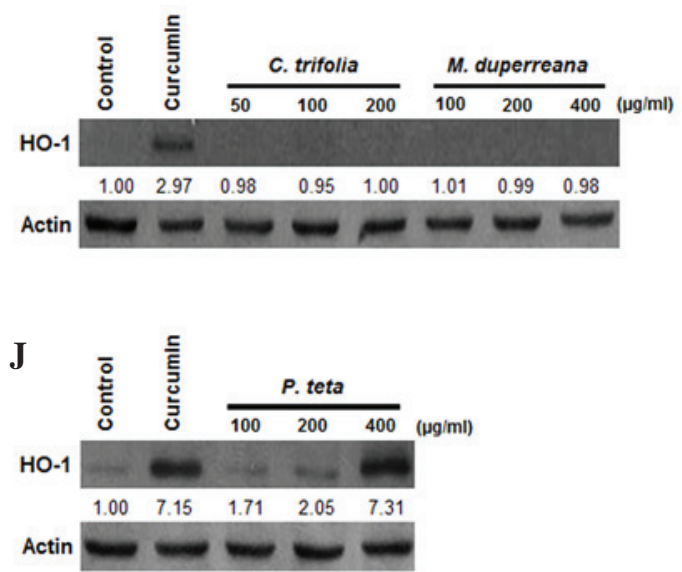

Figure 1. Effects of Cambodian plant extracts on the expression of HO-1 in HepG2 cells. (A-J) HepG2 cells were incubated for 12 h with the indicated concentrations of Cambodian plant extracts. Western blot analysis was performed to determine the expression of HO-1. HO-1, heme oxygenase-1.

the suppression of $t$-BHP-induced ROS generation (Fig. 3C and D).

Effects of T. crispa and P. weberi extracts on the nuclear translocation of Nrf2. The nuclear translocation of activated Nrf2 is a key upstream regulator for the expression of HO-1 (23). Therefore, the present study examined whether treatment of cells with $T$. crispa or $P$. weberi extracts induced the translocation of Nrf2 into the nucleus. The results of the western blot analysis revealed the presence of Nrf2 proteins in the nuclear compartment of HepG2 cells. The cells were incubated with $400 \mu \mathrm{g} / \mathrm{ml} \mathrm{T}$. crispa or P. weberi extracts for $0.5,1$ and $1.5 \mathrm{~h}$. As shown in Fig. 4A and B, the nuclear fractions of the T. crispa or $P$. weberi extract-treated cells exhibited a gradual increase in the levels of $\mathrm{Nrf} 2$, and the levels of Nrf2 simultaneously decreased in the cytoplasmic fractions.

\section{Discussion}

Previous studies have shown that several medicinal plants, including Curcuma longa and Glycyrrhiza glabra exert hepatoprotective effects by quenching ROS, which is a primary cause of oxidative damage in hepatocytes (24). HO-1, a heme-degrading enzyme, is involved in anti-inflammatory, anti-apoptotic and antiproliferative effects under various conditions (13). The induction of HO-1 is also likely to be a key therapeutic target in hepato-oxidative damage (25). HepG2 cells have been shown to express HO-1 (26). Several lines of evidence suggest that $t$-BHP, often used as a model in biological investigations (27), induces apoptotic cell death in HepG2 cells through the depletion of GSH and increase in intracellular $\mathrm{Ca}^{2+}$ concentrations (28). Therefore, $t$-BHP was used as a cell-death-inducing agent or negative control in the 
A

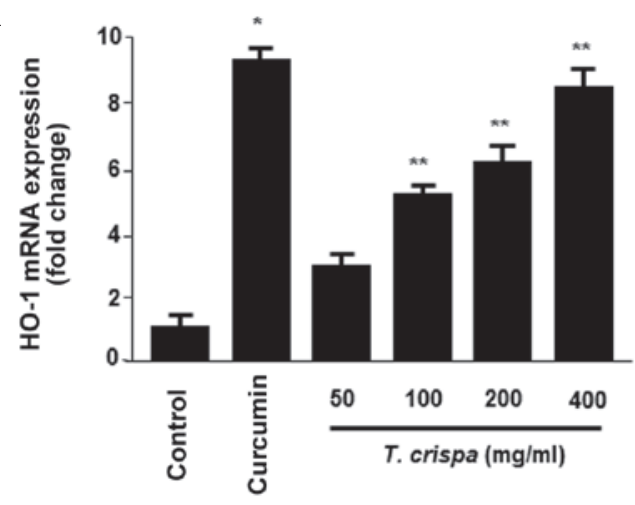

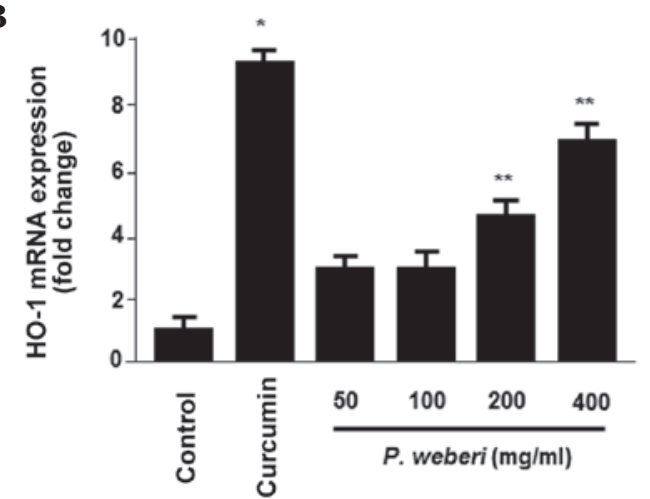

Figure 2. Involvement of the HO-1 pathway in the cytoprotective effects of T. crispa and P. weberi in HepG2 cells. HepG2 cells were pretreated for $3 \mathrm{~h}$ with (A) T. crispa (400 $\mu \mathrm{g} / \mathrm{ml})$ or (B) P. weberi $(400 \mu \mathrm{g} / \mathrm{ml})$ extracts in the presence or absence of SnPP $(50 \mu \mathrm{M})$, a competitive inhibitor of HO-1 activity, and stimulated for $12 \mathrm{~h}$ with $t$-BHP $(60 \mu \mathrm{M})$. The data are presented as the mean + standard deviation of three independent experiments. "P $<0.05$, compared with the control group; ${ }^{* *} \mathrm{P}<0.05$, compared with the group treated with $t$-BHP alone. HO-1, heme oxygenase-1; $t$-BHP, tert-butyl hydroperoxide; SnPP, Tin protoporphyrin IX.

A

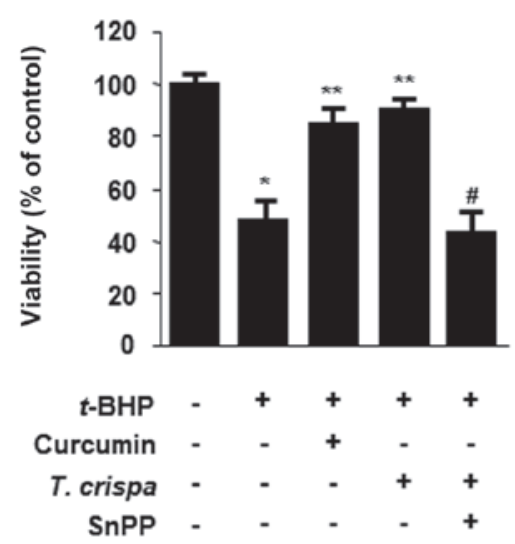

C

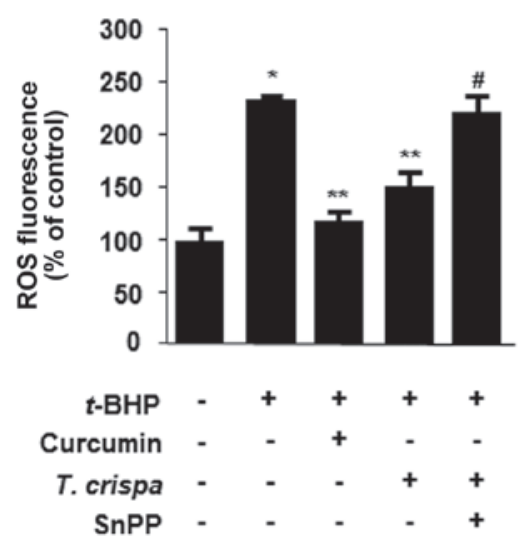

B

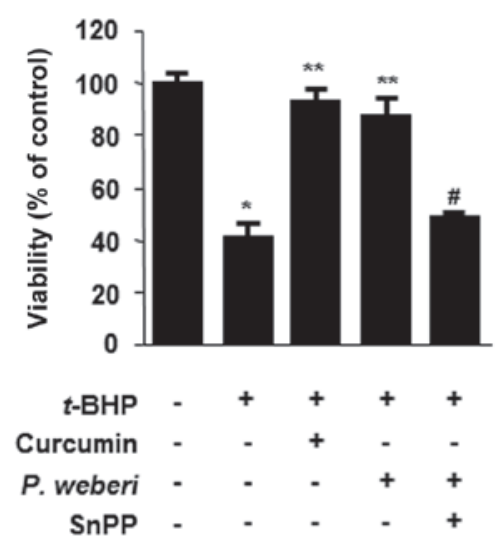

D

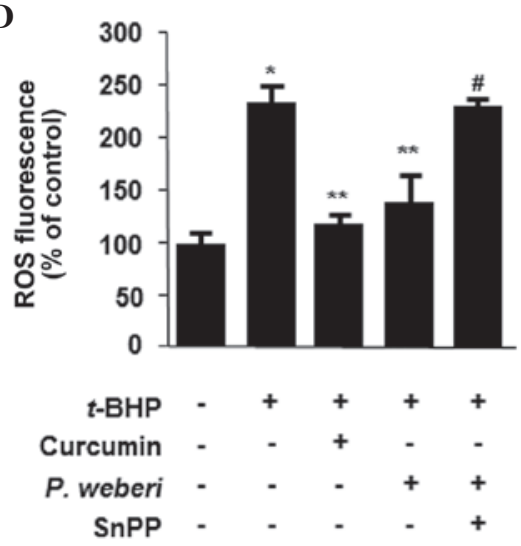

Figure 3. Effects of T. crispa and P. weberi extract-induced upregulation of HO-1 on $t$-BHP-induced hepatotoxicity and inhibition of ROS. HepG2 cells were treated with $400 \mu \mathrm{g} / \mathrm{ml}$ of (A) T. crispa or (B) P. weberi extracts in the presence or absence of $50 \mu \mathrm{M}$ of SnPP, and then exposed to $t$-BHP (60 $\mu \mathrm{M})$ for $12 \mathrm{~h}$. Exposure of HepG2 cells to $t$-BHP $(60 \mu \mathrm{M})$ for $12 \mathrm{~h}$ increased the production of ROS. (C) T. crispa or (D) P. weberi extract-induced upregulation of HO-1 effectively inhibited the production of ROS production. The data are presented as the mean + standard deviation of three independent experiments. "P<0.05, compared with the control group; ${ }^{* *} \mathrm{P}<0.05$, compared with the group treated with $t$-BHP alone; ${ }^{*} \mathrm{P}<0.05$, compared with the group treated with $T$. crispa $(400 \mu \mathrm{g} / \mathrm{ml})$ or $P$. weberi $(400 \mu \mathrm{g} / \mathrm{ml})$ in addition to $t$-BHP. HO-1, heme oxygenase-1; $t$-BHP, tert-butyl hydroperoxide; ROS, reactive oxygen species; SnPP, tin protoporphyrin IX.

present study. In identifying the hepatoprotective effects of the extracts in hepatocytes, curcumin has been extensively selected as a positive control to identify cytoprotective actions through the upregulation of HO-1 $(29,30)$. Therefore, curcumin was used as a positive control for the screening assay in the present study.

Based upon the results from the preliminary screening for hepatoprotective effects (Table I), 19 active plant extracts 
A
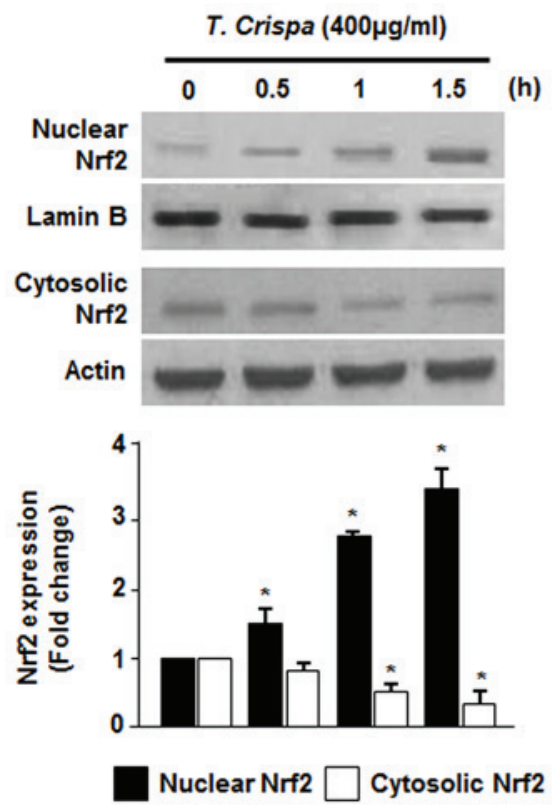
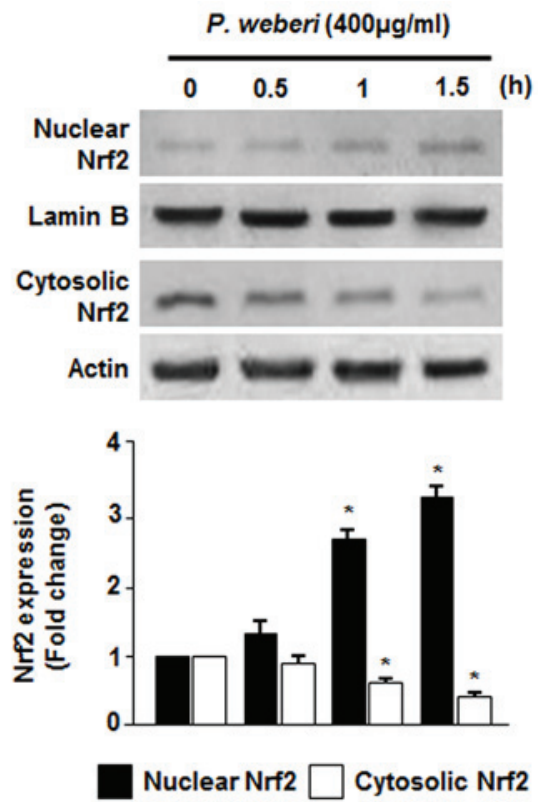

Figure 4. Effects of T. crispa or P. weberi extracts on the nuclear translocation of Nrf2. HepG2 cells were treated with $400 \mu \mathrm{g} / \mathrm{ml}$ of (A) T. crispa or (B) $P$. weberi extracts for $0.5,1$ and $1.5 \mathrm{~h}$. Nuclei were separated from the cytosol using NE-PER nuclear and cytoplasmic reagents. Western blot analysis was performed, and representative blots of three independent experiments are shown. The data are presented as the mean + standard deviation of three independent experiments. ${ }^{*} \mathrm{P}<0.05$, compared with the control group. Nrf2, nuclear factor E2-related factor 2.

were confirmed by performing an additional screen (Table II). HO-1 screening was then performed using western blot analysis (Fig. 1). The induction of cytoprotective enzymes is key to the cytoprotective mechanism. In the present study, it was shown that the ethanolic extracts of $T$. crispa and $P$. weberi induced the protein and mRNA expression levels of HO-1 and in HepG2 cells in a concentration-dependent manner (Figs. 1 and 2). In addition, pre-incubation of cells with the T. crispa or P. weberi extracts resulted in enhanced resistance to $t$-BHP-induced oxidative damage; this effect was attributable to the expression of HO-1 as the inhibition of $\mathrm{HO}$ enzyme activity by SnPP significantly reduced T. crispa/P. weberi extract-induced cytoprotection (Fig. 3). The induction of the expression of HO-1 was also required to suppress $t$-BHP-induced ROS generation. Several reports have indicated that secondary metabolites of plants can activate Nrf2 by binding to Kelch-like ECH-associated protein 1, leading to the upregulation of certain cytoprotective proteins, including HO-1 (15,31). This suggestion is in accordance with the findings of the present study showing that $T$. crispa or $P$. weberi extracts significantly increased the levels of Nrf2 and efficiently promoted the translocation of Nrf2 into the nuclei of HepG2 cells (Fig. 4). T. crispa, known as 'akar seruntum' or 'akar patawali' to the Malays, belongs to the family Menispermaceae and is native to China and Southeast Asia, including Malaysia. Extracts of T. crispa has been used in folk medicine as a therapeutic agent for the treatment of fever, jaundice, hyperglycemia, hypertension, wounds, intestinal worms and skin infections. In addition, several studies have revealed that $T$. crispa possesses anti-inflammatory, antioxidant, antiallergic, hepatoprotective, antithrombotic, antiviral and anticarcinogenic activities $(32,33)$. In the present study, the ethanolic extract from the aerial parts of T. crispa exerted cytoprotective effects on $t$-BHP-induced hepatotoxicity in HepG2 cells ( $\mathrm{EC}_{50} 144.3 \mu \mathrm{g} / \mathrm{ml}$; Table II). The cytoprotective activity may be attributed to the presence of alkaloids, diterpenoid lactones, sesquiterpenoids, phenolics and aliphatic compounds, which are generally found in T. crispa (34), which is partially indicated in Table II. $P$ weberi, widely distributed in Thailand, Lao, Malaysia and Southeast Asia, belongs to the family Liliaceae (35-37), which has antioxidant, antihypertensive, anticholinergic, antiasthmatic and antifungal actions $(38,39)$. In the present study, the leaf extract of $P$. weberi showed hepatoprotective activity against $t$-BHP-induced cytotoxicity in HepG2 $\left(\mathrm{EC}_{50} 121.7 \mu \mathrm{g} / \mathrm{ml}\right.$. The cytoprotective activity of $P$. weberi may be due to the presence of steroidal alkaloids (39). The ${ }^{1} \mathrm{H}-\mathrm{NMR}$ analyses of the ethanolic extracts of T. crispa and $P$. weberi revealed the presence of aliphatic or aromatic compounds (40) (data not shown), which may be responsible for the hepatoprotective properties of these plant extracts. In the 17 other extracts, a different mechanism may occur. Nrf2 induces genes encoding numerous phase II detoxifying enzymes, including HO-1, glutathione, catalase, superoxide dismutase, glutathione-S-transferase, $\gamma$-glutamyl cysteine ligase, NADPH quinone oxidoreductase-1, glutathione peroxidase and glutathione reductase $(15,16)$. Further extensive investigations are likely to provide evidence for the other representative mechanisms of hepatoprotection in plant extracts.

In conclusion, among 64 plants extracts from Cambodian medicinal plants, 19 plant extracts showed promising hepatoprotective activities. Of these, the extracts of T. crispa (aerial region) and $P$. weberi (whole plant) exerted potent cytoprotective effects against $t$-BHP-induced hepatotoxicity in human derived-HepG2 cells, possibly through the Nrf2-mediated expression of HO-1. Taken together, these results suggested that the ethalolic extracts of T. crispa and P. weberi may 
possess therapeutic applications in liver disease characterized by oxidative stress.

\section{Acknowledgements}

This study was supported by the Basic Science Research Program through the National Research Foundation of Korea funded by the Ministry of Education, Science and Technology (grant nos. 2012R1A1A2042984 and 2008-0062484).

\section{References}

1. Kham L (ed): Medicinal Plants of Cambodia: Habitat, Chemica Constituents and Ethnobotanical Uses. 1st edition. Bendigo Scientific Press, Golden Square, pp1-3, 2004.

2. Richman MJ, Nawabi S, Patty L and Ziment I: Traditional Cambodian medicine. J Complement Integr Med 7: 1-14, 2010.

3. World Health Organization. Health service delivery profile-Cambodia. Compiled in collaboration between WHO and Ministry of Health, Cambodia. Available at http://www.wpro. who.int/countries/ khm/en. Accessed April 24, 2014.

4. Ling CQ, Chiu JH, Oh B and Cho WC: Natural products for liver diseases: Basic, clinical and translational research. Evid Based Complement Alternat Med 2012: 794343, 2012.

5. El-Serag HB: Current concepts: Hepatocellular carcinoma. N Engl J Med 365: 1118-1127, 2011.

6. Czaja MJ: Cell signaling in oxidative stress-induced liver injury. Semin Liver Dis 27: 378-389, 2007.

7. Buc-Calderon P, Latour I and Roberfroid M: Biochemical changes in isolated hepatocytes exposed to tert-Butyl hydroperoxide. Implications for its cytotoxicity. Cell Biol Toxicol 7: 129-143, 1991.

8. Muriel P and Rivera-Espinoza Y: Beneficial drugs for liver diseases. J Appl Toxicol 28: 93-103, 2008.

9. Luper S: A review of plants used in the treatment of liver disease: Part 1. Altern Med Rev 3: 410-421, 1998.

10. Zhang A, Sun H and Wang X: Recent advances in natural products from plants for treatment of liver diseases. Eur J Med Chem 63: 570-577, 2013.

11. Schuppan D, Jia JD, Brinkhaus B and Hahn EG: Herbal products for liver diseases: A therapeutic challenge for the new millennium. Hepatology 30: 1099-1104, 1999.

12. Pae HO, Kim EC and Chung HT: Integrative survival response evoked by heme oxygenase- 1 and heme metabolites. J Clin Biochem Nutr 42: 197-203, 2008.

13. Otterbein LE, Soares MP, Yamashita K and Bach FH: Heme oxygenase-1: Unleashing the protective properties of heme. Trends Immunol 24: 449-455, 2003.

14. Fernandez M and Bonkovsky HL: Increased heme oxygenase-1 gene expression in liver cells and splanchnic organs from portal hypertensive rats. Hepatology 29: 1672-1679, 1999.

15. Shin SM, Yang JH and Ki SH: Role of the Nrf2-ARE pathway in liver diseases. Oxid Med Cell Longev 2013: 763257 2013.

16. Copple IM, Goldring CE, Kitteringham NR and Park BK: The Nrf2-Keap1 defence pathway: Role in protection against drug-induced toxicity. Toxicology 246: 24-33, 2008

17. Li YM: Alcoholism and alcoholic liver disease: Focusing on epidemiological investigation in Asia. Hepatobiliary Pancreat Dis Int 4: 170-172, 2005.

18. Banta JE, Addison A, Job JS, Yel D, Kheam T and Singh PN: Patterns of alcohol and tobacco use in Cambodia. Asia Pac J Public Health 25 (Suppl 5): S33-S44, 2013.

19. Kraisintu K: The status of medicinal and aromatic plants in Cambodia, Laos, the Philippines, Thailand and Vietnam. In: Longo $\mathrm{G}$ (ed). Medicinal Plants and Their Utilization. ICS-UNIDO, Trieste, pp3-9, 2003.
20. Hoshi $\mathrm{H}$ and Kan M: Growth factor assays for normal human hepatocytes and hepatoma cells. J Tissue Cult Meth 10: 83-92, 1986.

21. Livak KJ and Schmittgen TD: Analysis of relative gene expression data using real-time quantitative PCR and the 2(-Delta Delta C(T)) Method. Methods 25: 402-408, 2001.

22. Ghattas MH, Chuang LT, Kappas A and Abraham NG: Protective effect of HO-1 against oxidative stress in human hepatoma cell line (HepG2) is independent of telomerase enzyme activity. Int J Biochem Cell Biol 34: 1619-1628, 2002.

23. Gozzelino R, Jeney V and Soares MP: Mechanisms of cell protection by heme oxygenase-1. Annu Rev Pharmacol Toxicol 50: 323-354, 2010.

24. Luper S: A review of plants used in the treatment of liver disease: Part two. Altern Med Rev 4: 178-188, 1999.

25. Bauer M and Bauer I: Heme oxygenase-1: Redox regulation and role in the hepatic response to oxidative stress. Antioxid Redox Signal 4: 749-758, 2002

26. Gong P, Cederbaum AI and Nieto N: Heme oxygenase-1 protects HepG2 cells against cytochrome P450 2E1-dependent toxicity. Free Radic Biol Med 36: 307-318, 2004.

27. Van der Zee J, Barr DP and Mason RP: ESR spin trapping investigation of radical formation from the reaction between hematin and tert-butyl hydroperoxide. Free Radic Biol Med 20: 199-206, 1996.

28. Kim JA, Kang YS, Kim YO, Lee SH and Lee YS: Role of $\mathrm{Ca}^{2+}$ influx in the tert-butyl hydroperoxide-induced apoptosis of HepG2 human hepatoblastoma cells. Exp Mol Med 30: 137-144, 1998.

29. Cerný D, Lekić N, Váňová K, Muchová L, Hořínek A, Kmoníčková E, Zídek Z, Kameníková L and Farghali H: Hepatoprotective effect of curcumin in lipopolysaccharide/D-galactosamine model of liver injury in rats: Relationship to $\mathrm{HO}-1 / \mathrm{CO}$ antioxidant system. Fitoterapia 82 : 786-791, 2011.

30. McNally SJ, Harrison EM, Ross JA, Garden OJ and Wigmore SJ: Curcumin induces heme oxygenase 1 through generation of reactive oxygen species, p38 activation and phosphatase inhibition. Int J Mol Med 19: 165-172, 2007.

31. Itoh K, Chiba T, Takahashi S, Ishii T, Igarashi K, Katoha Y, Oyake T, Hayashi N, Satoh K, Hatayama I, et al: An Nrf2/small Maf heterodimer mediates the induction of phase II detoxifying enzyme genes through antioxidant response elements. Biochem Biophys Res Commun 236: 313-322, 1997.

32. Kadir FA, Othman F, Abdulla MA,Hussan F and Hassandarvish $P$ Effect of Tinospora crispa on thioacetamide-induced liver cirrhosis in rats. Indian J Pharmacol 43: 64-68, 2011.

33. Higashino H, Suzuki A, Tanaka Y and Pootakham K: Inhibitory effects of Siamese Tinospora crispa extracts on the carrageenin-induced foot pad edema in rats (the $1 \mathrm{st}$ report). Folia Pharmacologica Japonica 100: 339-344, 1992 (In Japanese).

34. Hipol RLB, Cariaga MFNM and Hipol RM: Anti-inflammatory activities of the aqueous extract of the stem of Tinospora crispa (Family Menispermaceae). J Nat Stud 11: 88-95, 2012.

35. Chaikla P, Suwanthada C and Trisonthi C: Morphological, anatomic and karyotypic characteristics of Peliosanthes teta Andrew. Afr J Agr Res 6: 6698-6705, 2011.

36. Eswani N, Kudus KA, Nazre M and Noor AGA: Medicinal plant diversity and vegetation analysis of logged over hill forest of Tekai Tembeling forest reserve, Jerantut, Pahang. J Agr Sci 2: 189-210, 2010.

37. Lundh ECS: Plant use in ante- and postpartum health care in Lao PDR (unpublished PhD thesis). Uppsala University, Uppsala, 2007.

38. Gupta VK and Sharma SK: Plants as natural antioxidants. Nat Prod Rad 5: 326-334, 2006.

39. Li HJ, Jiang Y and Li P: Chemistry, bioactivity and geographical diversity of steroidal alkaloids from the Liliaceae family. Nat Prod Rep 23: 735-752, 2006.

40. Silverstein RM, Webster FX and Kiemle DJ: Spectrometric identification of organic compounds, 7th edition. Hoboken: Wiley \& Sons; 141-142, 2005. 